Інноватика у вихованні. Випуск 12. 2020.

\author{
УДК 378.174
}

DOI: $10.35619 /$ iiu.v1i12.294

Проценко Ірина

кандидат педагогічних наук, доцент, доцент кафедри педагогіки

Сумського державного педагогічного університету імені А. С. Макаренка,

м. Суми, Україна

ORCID: 0000-0003-1792-7200, e-mail: procenkoira83@ukr.net

\title{
ФОРМУВАННЯ ТОЛЕРАНТНОСТІ У СТУДЕНТІВ ЗАКЛАДІВ ВИЩОЇ ОСВІТИ ЯК ПЕДАГОГІЧНА ПРОБЛЕМА
}

\begin{abstract}
Анотація. У статті на основі аналізу психолого-педагогічної літератури проаналізовано сутність поняття «толерантність» як терпеливе ставлення до інших людей, повага думки інших, вміння прислухатися, зрозуміти іншу людину. Розглядається питання формування толерантності у студентів як педагогічна проблема. Розроблено критерії діяльності педагога, спрямовані на формування толерантності у студентів педагогічних закладів вищої освіти. Визначено причини несформованості толерантності: соціально-економічні проблеми в сім'ї та суспільстві, природні катаклізми, виховна інерція батьків стосовно дітей, агресія, що панує з екранів телевізорів.

На основі аналізу зарубіжної та вітчизняної науково-педагогічної літератури визначено, що толерантність - це терпляче ставлення до інших людей, повага думки іншого, вміння прислухатися, зрозуміти іншу людину; це особистісна властивість, яка проявляється в спілкуванні i полягає в самовладанні, поважності, розумінні, емпатії інших людей, навіть якщо їх думки, упередження, расова або релігійна приналежність відмінні від ваших.

У представленій статті розроблено умови та етапи формування толерантності в освітньому процесі. Охарактеризовано основні види толерантності: вроджена та придбана толерантності. Визначено, що виховання в дусі толерантності має бути спрямоване на протидію впливу, що викликає почуття страху і відчуження у взаєминах з іншими.

Ключові слова: толерантність, інтолерантність, освітній процес, формування толерантності, студенти педагогічних закладів вищої освіти, виховання.
\end{abstract}

Постановка проблеми. Процеси глобалізації, зростаюча мобільність, відкриті ринки праці, міграційні потоки призводять до актуалізації проблеми формування толерантності у студентів закладів вищої світи (ЗВО).

Вища освіта передбачає підготовку професіоналів для різних областей науки і техніки. Випускники ЗВО стають не тільки кваліфікованими працівниками, а й виконують соціальні функції: взаємодіючи 3 іншими людьми, вони повинні вміти працювати в команді, вміти чути думку інших людей, уникати конфліктних ситуацій, знаходити компроміс. Важливою умовою для реалізації цих цілей $\epsilon$ формування толерантності, а також дотримання принципу толерантності при організації освітнього процесу у закладах вищої освіти. 
Аналіз актуальних досліджень. Проблемі формування толерантної особистості присвячені дослідження Г. Олпорта, А. Асмолова, Г. Солдатової, В. Тишкова, Є. Луковицького, Е. Селезньової, В. Бойка, К. Абдульханової, Л. Дикої, В. Семикіної, Л. Митиної. Спроба теоретичного аналізу поняття толерантність зроблена О. Хеффе, Ю. Іщенко, І. Ксенофонтовим, В. Лекторським, І. Йовель. Дослідження Е. Іллінської, Л. Коломійченка, Ф. Пак, Н. Асташової, М. Степанова та інших спрямовані на вивчення проблеми формування толерантної особистості в дошкільному віці.

У своїх працях С. Баранов, С. Бондирева, Д. Колесов розглядають толерантність як соціально-психологічний феномен в умовах соціально-етнічних змін. Д. Петров аналізує поняття, толерантної взаємодії з погляду психології спілкування - як прояв індивідуальної моральної позиції людини, особливостей іiі психоемоційного розвитку (Петрова, 2017).

Проблеми етнічної толерантності в полікультурному суспільстві розробляються А. Гусєйновою, Л. Дробіжевою, П. Гречко, А. Асмоловим. У своїх роботах вони досліджують умови, що сприяють виникненню етнічної толерантності, а саме: етнічна ідентичність і географічна мобільність, визначають поняття «соціального» і «етнічного статусу» (Гусєйнова, 2015).

Особливу роль відіграє проблема підготовки майбутніх педагогів у контексті толерантної свідомості. Багато дослідників, зокрема Т. Білоус, Т. Завгородня, Ю. Подборскій, Д. Крамаренко, М. Окса, М. Липа відзначають особливу цінність ролі сучасного педагога в формуванні толерантності студентів (Петрова, 2017)

Мета статті - визначити основні критерії формування толерантності у студентів закладів вищої освіти та перевірити їх ефективність.

Виклад основного матеріалу дослідження. Термін «толерантність» відносно молодий в науці. Дотепер склалися різні підходи щодо визначення толерантності залежно від специфіки дисципліни і теоретичних постулатів, у рамках яких розглядається це поняття.

Толерантність - не пасивне підпорядкування думці інших, а активна моральна позиція і психологічна готовність до терпимості для досягнення взаєморозуміння 3 людьми різної культурної, національної, релігійної або соціального середовища.

Термін «толерантність» був введений в науковий тезаурус французьким філософом i політичним діячем Антуаном Луї Клодом Дестют де Трасі (Рибченко, 2016). До сьогодні в західній соціології та політології толерантність $\epsilon$ одним 3 основних демократичних принципів, нерозривно пов'язаних 3 концепціями плюралізму, соціальної свободи та прав людини (Іллінська, 2007).

Формування розуміння толерантності здійснювалося протягом двох століть. Латинське слово «toleranten», яке стало похідним для поняття толерантності, позначає стійкість, несприйнятливість до зовнішніх змін, і довгий час було терміном суто медичним, біологічним. Але сьогодні 3 загальною тенденцією дифузії між гуманітарними, соціальними, природними, точними науками i, відповідно, зближенням понять, він об'єктивно набуває іншого значення. Воно лише частково пов'язане з його первородним змістом (Петрова, 2017).

Відповідно до Декларації принципів толерантності, затвердженої резолюцією 5.61 Генеральної конференції ЮНЕСКО від 16 листопада 1995 року, толерантність означає «повагу, прийняття і правильне розуміння багатого 
різноманіття культур нашого світу, наших форм самовираження і способів проявів людської індивідуальності (Декларація принципів толерантності).

В. Долгова визначила толерантність як взаєморозуміння на основі згоди, поваги, розуміння, визнання рівноправності, відмова від тиску і насильства, визнання права інших на свої думки і погляди, прийняття людей такими, якими вони є (Долгова, 2016).

У працях Д. Нерознак, Г. Сунгурова і Н. Еліасберг поняття «толерантність» тлумачиться як: здатність особистості, суспільства, держави шанобливо сприймати думку інших, яка $є$ відмінною від їхньої; готовність безконфліктно сприймати особистість або явища; шанобливо ставитись до свободи іншого, його способу життя, поведінки, думок, не залежно від його політичних та релігійних поглядів; прояв терпимості і прийняття представників інших культур, релігій i країн; повага до форм самовираження i прояву людської індивідуальності.

Отже, толерантність $є$ одним з гарантів суспільної стабільності в сучасному світі.

Причинами несформованості толерантності можуть бути соціальноекономічні проблеми в сім'ї та суспільстві, природні катаклізми, виховна інерція батьків стосовно своїх дітей, агресія, що панує з екранів телевізорів. Усунути ці причини не можна, але необхідно їх «затьмарити» шляхом виховання співчуття, вміння спілкуватися і знаходити компроміси в різних конфліктних ситуаціях, бути поблажливішим до різних націй, виявляти цікавість і почуття поваги до інших народів за допомогою музейної педагогіки, здатності жити в світі різних людей та ідей.

У сучасній літературі «толерантність» часто виступає синонімом визначення «терпимість» і тлумачиться як «терпимість до чужого способу життя, поведінки, звичаїв, ідеям, віруванням» (Гусєйнова, 2015). Толерантність передбачає здатність людини вийти за межі свого світу, зрозуміти і прийняти інший світ, відмінний від його власного, за багатьма ознаками: національними, культурними, релігійними та ін.

Науковці Д. Петрова, Н. Еліасберг, Г. Сунгурова, Д. Нерознак пропонують такі визначення толерантності: здатність людини, спільноти і держави чути, а також поважати думку інших, доброзичливо зустрічати відмінне від своєї думки; готовність i здатність без протесту сприймати особистість i явище; взаєморозуміння; повага свободи іншого, його способу мислення, поведінки, політичних i релігійних поглядів; повага, прийняття, правильне розуміння різноманіття культур нашого світу, форм самовираження і прояву людської індивідуальності (Петрова, 2017).

Визначення терміна «толерантність» для всього Європейського союзу подано в «Програмі формуванні установок толерантної свідомості і профілактики екстремізму» на основі «Декларації принципів толерантності» як: цінність і соціальна норма громадянського суспільства; забезпечення стійкої гармонії і конструктивної взаємодії між різними соціальними групами; повага до різноманітності різних світових культур, цивілізацій і народів; готовність до порозуміння та співпраці 3 людьми, які відрізняються зовнішньо, мовою спілкування, переконаннями, звичаями i віруваннями; навички ефективної міжкультурної взаємодії.

Сучасні тлумачення поняття і сутності толерантності в зарубіжній літературі piзні. Американське видання «American Heritage Dictionary» визначає 
толерантність як здатність до визнання або практичне визнання i повагу переконань і дій інших людей, яке базується на взаємоповазі суб єктами один до одного.

Вивчивши досвід вітчизняної та зарубіжної літератури з цієї проблеми, дамо визначення толерантності. Толерантність - це терпляче ставлення до інших людей, повага думки іншого, вміння прислухатися, зрозуміти іншу людину; це особистісна властивість, яка проявляється в спілкуванні i криється в самовладанні, поважності, розумінні, емпатії інших людей, навіть якщо їх думки, упередження, расова або релігійна приналежність відмінні від ваших.

Виховання в дусі толерантності має бути спрямоване на протидію впливу, що викликає почуття страху і відчуження у ставленні до інших, що сприяє формуванню у молоді навичок незалежного мислення, критичного осмислення й вироблення суджень, заснованих на моральних цінностях.

Опитування студентів Сумського державного педагогічного університету імені А. С. Макаренка (брало участь 108 студентів I і II курсів) про бажані особистісні якості викладача також підтвердили, що реалізація двох основних функцій викладача - виховання і навчання - вимагає від сучасного педагога таких особистісних параметрів: тактовності, емпатії, терплячості, терпимості у стосунках зі студентами та іншими викладачами, готовності приймати i підтримувати їх; розуміння своєрідності і автономності особистості студента; вміння забезпечувати внутрішньогрупове і міжгрупове спілкування, вміння запобігати виникненню конфліктів.

Однак за результатами цього опитування з'ясувалося, що 49\% викладачів вузу, на думку студентів, організовують навчально-виховний процес, грунтуючись на демократичному стилі спілкування, 13\% - на ліберальному. 38\% - на авторитарному.

У свою чергу було проведено анкетування викладачів 3 ВО (всього брало участь 52 викладачі) «Критерії і показники готовності до формування толерантності у студентів» (таблиця 1), результати якого засвідчили, що не всі готові до формування толерантності у студентів.

Таблиця 1

Критерії та показники формування толерантності

\begin{tabular}{|c|c|}
\hline Критерії & Показники \\
\hline $\begin{array}{l}\text { Стійкість особистості - сформованість } \\
\text { соціально-моральних } \\
\text { поведінки особистості } \quad \text { в } \quad \text { процивів } \\
\text { взаємодії з людьми інших спільнот }\end{array}$ & $\begin{array}{l}\text { Емоційна стабільність, } \\
\text { доброзичливість, ввічливість, терпіння, } \\
\text { соціальна відповідальність, } \\
\text { самостійність, соціальна релаксація }\end{array}$ \\
\hline $\begin{array}{l}\text { Емпатія - адекватне уявлення про те, } \\
\text { що відбувається у внутрішньому світі } \\
\text { іншої людини }\end{array}$ & $\begin{array}{l}\text { Високий рівень співпереживання, } \\
\text { чемність, екстравертність, здатність до } \\
\text { рефлексії }\end{array}$ \\
\hline $\begin{array}{l}\text { Дивергентність мислення - орієнтація } \\
\text { на пошук декількох варіантів } \\
\text { вирішення проблеми }\end{array}$ & $\begin{array}{l}\text { Відсутність забобонів, стереотипів, } \\
\text { гнучкість і критичність мислення }\end{array}$ \\
\hline $\begin{array}{l}\text { Мобільність поведінки - здатність до } \\
\text { швидкої зміни стратегії з урахуванням } \\
\text { обставин }\end{array}$ & 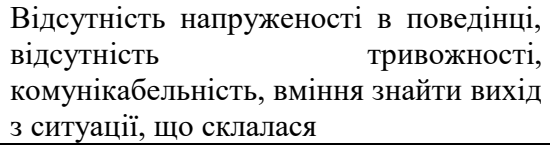 \\
\hline $\begin{array}{l}\text { Соціальна активність }- \text { готовність } \\
\text { взаємодії в різних ситуаціях, } 3 \text { метою }\end{array}$ & $\begin{array}{l}\text { Соціальна самоідентифікація, } \\
\text { соціальна адаптованість, креативність, }\end{array}$ \\
\hline
\end{tabular}


Інноватика у вихованні. Випуск 12. 2020.

\begin{tabular}{|c|c|}
\hline конструктивних & соціальний оптимізм, ініціативність \\
\hline Знання самого себе & $\begin{array}{l}\text { Намагається розібратися в своїх } \\
\text { перевагах і недоліках, оцінює себе } \\
\text { критично, не прагне в бідах і } \\
\text { неприємностях звинуватити інших. «Я- } \\
\text { ідеальне» і «Я-реальне» мають великий } \\
\text { розрив, має високий потенціал для } \\
\text { саморозвитку }\end{array}$ \\
\hline Захищеність & $\begin{array}{l}\text { Відчуває себе в безпеці, не прагне } \\
\text { захищатися від інших людей }\end{array}$ \\
\hline Відповідальність & $\begin{array}{l}\text { Не перекладає } \\
\text { завжди годповідальність, } \\
\text { вчинки }\end{array}$ \\
\hline Потреба у визначенні & Бачить світ в його різноманітті \\
\hline Орієнтація на себе або інших & $\begin{array}{l}\text { Орієнтований на себе в роботі, творчий } \\
\text { процес, на роздуми, у проблемних } \\
\text { ситуаціях схильний звинувачувати } \\
\text { себе, а не оточуючих, прагне до } \\
\text { особистої незалежності }\end{array}$ \\
\hline Здатність до емпатії & $\begin{array}{l}\text { Здатний до співпереживання, } \\
\text { соціальної } \\
\text { формулювати правильні судження про } \\
\text { інших }\end{array}$ \\
\hline Почуття гумору & $\begin{array}{l}\text { Здатний пожартувати над собою, } \\
\text { самокритичний, не прагне до переваги } \\
\text { над іншими }\end{array}$ \\
\hline Ставлення до авторитаризму & $\begin{array}{l}\text { Віддає перевагу будувати спілкування } \\
\text { на демократичному основі }\end{array}$ \\
\hline
\end{tabular}

Опитування також засвідчило, що для студентів важливими якостями викладачів $\epsilon$ : знання предмета, культура, професіоналізм, привітність, неконфліктність. Багато із зазначених очікуваних студентами якостей викладача є характеристиками толерантної особистості. Це ще раз переконує, що необхідно створювати установку на формування толерантності у викладачів, а потім у студентів.

Висновки і перспективи подальших розвідок. Підсумовуючи проведений аналіз, можна стверджувати, що формування толерантності - це створення умов для формування певних властивостей і якостей особистості студентів, що передбачає: духовність педагогічної культури викладачів, здатних спрямовувати освітній процес на розкриття самоцінності людини; пріоритетність розвитку особистості, що володіє почуттям власної гідності, внутрішньою свободою і відповідальністю; орієнтування на утримання освітнього процесу, в якому навіть у предметах, далеких від гуманітарної проблематики, присутні моменти світоглядного характеру, інтерес до різних поглядів і думок, переконань та способів вирішення.

Педагог у процесі формування толерантності повинен враховувати навички групової комунікації, вміння практично мислити, демонструвати та давати знання в галузях політики, культури, прав людини, національних відносин. 
Отже, формування толерантності передбачає цілеспрямовану і обгрунтовану побудову освітнього процесу, вибір змісту, дидактичних засобів і методів навчання, а також організацію позанавчальної діяльності.

\section{СПИСОК ВИКОРИСТАНИХ ДЖЕРЕЛ}

Петрова, Д. (2017). Можливості використання педагогічного моделювання у формуванні толерантності та гуманізму. Сучасна педагогіка. № 7.

Гусєйнова, Є. (2015). Основні підходи до вивчення поняття толерантності у сучасній та зарубіжній науці. Молодий вчений, № 21.

Рибаченко, К. (2016). Порівняльний аналіз комунікативної толерантності викладачів та студентів університетів. Сучасні наукові дослідження та інновації. № 5

Іллінська, С. (2007). Толерантність. Молодий учений. № 4.

Декларація приничипів толерантності. URL: https://zakon.rada.gov.ua/laws/show/995_503\#Text [Дата останнього звернення 24.10.2020]

Долгова, В. (2016). Психологічні детермінанти розвитку толерантності іноземних студентів у педагогічних університетах. Науково-методичний електронний журнал, T. 7

Гаврутенко, Т. (2010). Структурно-функціональна модель управління проєктною діяльністю вчителів. Світ науки, культури, освіти, 5 (24), 127-130.

Грушнікова, Є. (2015). Управління підвищенням кваліфікації педагогів у мережевій взаємодії освітніх організацій. Сучасні проблеми науки та освіти. URL: http://science-education.ru [Дата останнього звернення 24.10.2020]

Зимовіна, О. (2011). Виховання толерантності студентів: теоретикометодологічний аспект. Гуманізація освіти, № 3 .

Клесова, С. (2012). Виховання толерантності у студентській молоді. Молодий учений, № 4 .

Козлова, А. (2010). Формування толерантності молоді в університеті. Альманах современной науки и образования, № 1 (32).

Мичка, С.(2015). Соціальна взаємодія у студентському колективі. Молодий учений, № 4 (15).

Філософський енииклопедичний словник. URL: http://shron1.chtyvo.org.ua/Shynkaruk_Volodymyr/Filosofskyi_entsyklopedychnyi_sl ovnyk.pdf

\section{REFERENCES}

Petrova, D. (2017). Mozhlyvosti vykorystannia pedahohichnoho modeliuvannia u formuvanni tolerantnosti ta humanizmu [Possibilities of using pedagogical modeling in the formation of tolerance and humanism] Suchasna pedahohika. No 7. [in Ukrainian]

Huseinova, Ye. (2015). Osnovni pidkhody do vyvchennia poniattia tolerantnosti u suchasnii ta zarubizhnii nautsi [Basic approaches to the study of the concept of tolerance in modern and foreign science] Molodyi vchenyi, No 21. [in Ukrainian]

Rybachenko, K. (2016). Porivnialnyi analiz komunikatyvnoi tolerantnosti vykladachiv ta studentiv universytetiv [Comparative analysis of communicative tolerance of university teachers and students] Suchasni naukovi doslidzhennia ta innovatsii. No 5. [in Ukrainian]

Illinska, S. (2007). Tolerantnist [Tolerance] Molodyi uchenyi. No 4. [in Russian] 
Deklaratsiia pryntsypiv tolerantnosti [Declaration of Principles of Tolerance]. URL: https://zakon.rada.gov.ua/laws/show/995_503\#Text [Data ostannoho zvernennia 24.10.2020] [in Ukrainian]

Dolhova, V. (2016). Psykholohichni determinanty rozvytku tolerantnosti inozemnykh studentiv u pedahohichnykh universytetakh [Psychological determinants of the development of tolerance of foreign students in pedagogical universities] Naukovo-metodychnyi elektronnyi zhurnal, T. 7. [in Ukrainian]

Havrutenko, T. (2010). Strukturno-funktsionalna model upravlinnia proiektnoiu diialnistiu vchyteliv [Structural and functional model of project management of teachers.] Svit nauky, kultury, osvity, 5 (24), C. 127-130. [in Ukrainian]

Hrushnikova, Ye. (2015). Upravlinnia pidvyshchenniam kvalifikatsii pedahohiv u merezhevii vzaiemodii osvitnikh orhanizatsii [Management of advanced training of teachers in network interaction of educational organizations] Suchasni problemy nauky ta osvity. URL: http://science-education.ru[Data ostannoho zvernennia 24.10.2020] [in Ukrainian]

Zymovina, O. (2011). Vykhovannia tolerantnosti studentiv: teoretykometodolohichnyi aspect [Education of students' tolerance: theoretical and methodological aspect] Humanizatsiia osvity, No 3. [in Ukrainian]

Klesova, S. (2012). Vykhovannia tolerantnosti u studentskii molodi [Education of tolerance in student youth] Molodyi uchenyi, No4. [in Ukrainian]

Kozlova, A. (2010). Formuvannia tolerantnosti molodi v universyteti [Formation of youth tolerance at the university] Almanakh sovremennoi nauky y obrazovanyia, No 1 (32). [in Ukrainian]

Mychka, S.(2015). Sotsialna vzaiemodiia u studentskomu kolektyvi [Social interaction in the student body.] Molodyi uchenyi, No 4 (15). [in Ukrainian]

Filosofskyi entsyklopedychnyi slovnyk [Philosophical encyclopedic dictionary] URL:

http://shron1.chtyvo.org.ua/Shynkaruk_Volodymyr/Filosofskyi_entsyklopedychnyi_sl ovnyk.pdf [in Ukrainian]

\title{
FORMATION OF TOLERANCE FOR STUDENTS OF HIGHER EDUCATION INSTITUTIONS AS A PEDAGOGICAL PROBLEM
}

\author{
Iryna Protsenko \\ Candidate of Pedagogical Sciences, Associate Professor, \\ Associate Professor at the Department of Pedagogy, \\ Sumy A.S. Makarenko State Pedagogical University \\ Sumy, Ukraine \\ ORCID: 0000-0003-1792-7200, \\ e-mail: procenkoira83@ukr.net
}

\begin{abstract}
The article, based on the analysis of psychological and pedagogical literature, analyzes the essence of the concept of «tolerance», as a patient attitude to other people, respect for the opinions of others, the ability to listen, understand another person. The issue of forming students' tolerance as a pedagogical problem is considered. Criteria for teacher activity have been developed, which is aimed at forming tolerance in students of pedagogical institutions of higher education. The reasons for the lack of tolerance are identified: socio-economic problems in the family
\end{abstract}


and society, natural disasters, educational inertia of parents towards children, aggression that prevails on TV screens.

Based on the analysis of foreign and domestic scientific and pedagogical literature, it is determined that tolerance is a patient attitude to other people, respect for the opinion of others, the ability to listen, understand another person; it is a personal property that is manifested in communication and consists in self-control, respect, understanding, empathy of other people, even if their thoughts, prejudices, racial or religious affiliation are different from their own

It was found that the teacher in the process of forming tolerance should take into account the skills of group communication, the ability to think practically, to give knowledge in the field of politics, culture, human rights, national relations. The article presents the results of a survey of students of higher education and teachers on the two functions of the educational process - education and training.

In the presented article the conditions and stages of formation of tolerance in the educational process are developed. The main types of tolerance are characterized: innate and acquired tolerance. It is determined that education in the spirit of tolerance should be aimed at counteracting the influence that causes feelings of fear and alienation from others.

Key words: tolerance, intolerance, educational process, the formation of tolerance, students of pedagogical higher educational institutions, education.

Стаття надійшла до редакиії 07. 10. 2020 р. 